\title{
Implementation of Student Facilitator And Explaining Model To Support The Active, Innovative and Enjoyable Learning in Social Science Learning in 2013 Curriculum-Based Elementary School
}

\author{
Murtiningsih \\ Elementary School Teacher Education \\ Universitas Negeri Malang \\ Malang, Indonesia \\ murtiningsih.ksdp@yahoo.com
}

\begin{abstract}
Selection of appropriate learning model can support the achievement of a learning objective. In the learning of social science (IPS), it is necessary for a model that can assist the students in developing thinking activity and creativity. One of the effective models in social science learning in the elementary school is Student Facilitator and Explaining learning model. The social science learning with the Student Facilitator and Explaining learning model provides opportunities for the students to train their verbal skills. This is applied by practicing what they have learned, practicing their bravery and self-confidence, and providing an opportunity for the students to explain to their friends. This can also encourage students' interest at the learning so that it will be enjoyable for the students. The Student Facilitator and Explaining learning model are greatly appropriate to be applied for the social science in in 2013 curriculum-based elementary school.
\end{abstract}

Keywords - the student facilitator and explaining learning model, social science, 2013 curriculum, elementary school

\section{INTRODUCTION}

In the education in a globalization era, a teacher is required to be more creative in implementing learning at school because students can obtain various information from a wide range of information media. Since students can easily obtain information from a wide range variety of media, then there is an increasingly broad pattern development of student thinking pattern. The student thinking pattern is formed by the information progress, therefore it is necessary to get the teacher's attention. It is also necessary for teachers to guide students so that they can obtain increasingly developed knowledge and not misdirected one.

There are many ways that can be applied by teachers, one of which is to create a variety of learning activities, namely the learning directed to active and innovative activities. Through the learning atmosphere, it is expected to lead to students' more critical, brave, confident thinking pattern development. One of the learning models is the Student Facilitator And Explaining learning model because this model is one of the student-centered models. Learning strategy using the Student Facilitator And Explaining model should be used in IPS learning in elementary school because it can create an independent person growing students to have self-esteem.

\section{LITERATURE REVIEW}

\section{A. Basic Concept and Purposes of Student Facilitator and Explaining Learning Model}

Conceptually, the Student Facilitator and Explaining (SFAE) is a learning model giving an opportunity for students to practice to represent their ideas to other students [1]. In the learning activity with the Student Facilitator and Explaining (SFAE) learning model, teachers present materials to students by providing examples previously, then giving an opportunity for students to explain to their friends about the material understanding that has been learned.

In the Student Facilitator And Explaining (SFAE) learning model, at first teacher begins the learning by giving an explanation on the material outlines to be studied, then provides opportunities for students to study the material, afterwards the students are given the opportunity to explain to their friends about the material learned and finally all materials are presented to students.

The purposes of Student Facilitator And Explaining (SFAE) learning model are: (1) Train students to actively think, (2) train students to find their own way to deepen any materials they are learning on, (3) train students to have bravery to present to their friends about any things they learn.

\section{B. Implementation of Student Facilitator and Explaining (SFAE) Learning Model}

The implementation stages of Student Facilitator And Explaining [1]: (a) teacher presents the competencies to be achieved, (b) the teacher demonstrates or presents outlines of the subject matter to be studied, (c) teacher provides opportunities for students to find their own way to deepen the materials they are learning on, (d) teacher provides opportunity for students to explain to their other friends about the lessons learned either through charts, concept maps, or others. This can be done in turns or randomly, (e) 
teacher summarizes students' ideas or opinions, (f) the teacher explains the material presented at the time and $(\mathrm{g})$ closing.

Meanwhile, the implementation stages of Student Facilitator And Explaining (SFAE): (a) Preparation includes any activities conducted by teachers in the planning stage, among others: (1) preparing lesson plan based on the main discussion, (2) determining which parts of material to be presented, (3) preparing learning media, (4) preparing students' worksheets. (b) implementation includes: (1) PreActivity: teacher presents opening greeting, prayer, and presentation. (2) Initial Activity includes: teacher conducts apperception, the teacher describes materials to be learned, and the teacher delivers the learning purposes. (3) Core Activity, teacher conducts the learning based on the implementation stages of Student Facilitator And Explaining (SFAE) including: The teacher conveys the competence to be achieved, (b) the teacher demonstrates or presents an outline of the subject matter to be studied, (c) lets the students find themselves to deepen the things they are learning, (d) gives students the opportunity to explain To other friends about the lessons learned either through charts, concept maps, or others. This can be done in turns or randomly, (e) the teacher summarizes the ideas or opinions of the students, (f) the teacher explains the material presented at the time. (4) Final Activity, the teacher guides students to draw a conclusion on the materials that have been learned, then make an evaluation, reflection, and end by prayer.

Advantages and Disadvantages of Student Facilitator And Explaining (SFAE). Advantages of Student Facilitator And Explaining (SFAE) among others are: (1) creating more clear and concrete subject materials. (2) increasing students' absorptive capacity because the learning is conducted through demonstration. (3) training students to practice to be a teacher because they are given the opportunity to repeat teacher's explanations in front of other students. (4) Encouraging students' motivation to be the best in explaining subject materials. (5) determining students' ability in delivering ideas isadvantages of Student Facilitator And Explaining (SFAE) among others are: (1) there are many less active or shy students facing difficulty to demonstrate what the teacher is instructing. (2) not all students have the same opportunity to explain to other students. (3) there are the same opinions so that there are only a few skilled students [2].

\section{Social Science (IPS)}

\section{1) Definition of IPS}

IPS according to Sumaatmaja is one of the subjects or courses to study on human social life which its study integrates fields of social sciences and humanity[3]. According to Somantri [3] he stated that the IPS education is a simplification or adaptation of social science and humanity disciplines, as well as basic human activities that are organized and presented in a scientific and pedagogic/psychologic manner or the sake of educational purposes. According to Hidayati [4] she stated that the IPS is the integration of various branches of social sciences such as sociology, cultural anthropology, social psychology, history, geography, economics, political science, Meanwhile, according to KTSP 2006 [5], IPS is a subject that examines a set of events, concepts, and generalizations related to social science. Through the IPS subject, learners are directed to become democratic, responsible and citizens of Indonesia, as well as a peace-loving world citizen. Based on the above opinions, it can be concluded that a definition of social science is a subject learning on human social life which its study integrates social science branches such as sociology, history, geography, anthropology, economics, politics and social psychology.

\section{2) Purposes of IPS in Elementary school level}

According to Sumaatmaja [6] the purpose of IPS is to foster students to be good citizens having knowledge, skills and social concerns that are useful for themselves and for the community and the State. Meanwhile, according to Trianto [7], the purposes of IPS are to develop learners' potential so that they can be sensitive to social problems facing in the community, having positive mental attitude towards improvement on all existing inequities, and being skillfully to overcome every problem faced in daily life by themselves or to the community. The purpose of IPS is to create students to have the following skills [5]: (1) to know any concepts related to the life of the community and the surrounding environment; (2) to have basic skills for logical and critical thinking, curiosity, inquiry, problem solving, and skills in social life; (3) to have commitment and awareness of social and humanitarian values; (4) to have the ability to communicate, cooperate, and compete in a pluralistic society, locally, nationally and globally. While the scope of IPS, covers the following aspects: (1) Man, place, and environment. (2) Time, sustainability and change. (3) Social and cultural systems. (4) economic behavior and welfare.

While the IPS learning objective according to the NCSS (National Council for Social Studies) is to assist younger generations so that they have ability in: (1) developing their ability to become knowledgeable human being; (2) developing intelligence in making decisions for the sake of community interest as citizens in which there is a culture, and (3) becoming a democratic society citizen in an interdependent world [8].

\section{3) Scope of IPS}

The scope of IPS learning studies on a set of events, facts, concepts, and generalizations related to social issues. According to Mulyasa [9] the scope of IPS covers the following aspects: (a) human, place, and environment; (B) time, sustainability, and change; (C) social and cultural systems; (D) behavior, economy, and well-being. Through IPS subject, students are directed to become democratic, responsible Indonesian citizens, and become citizens of a peace-loving world. Therefore, the IPS subject is designed to develop knowledge, understanding, and analytical skills on the social conditions faced in the community when they enter a dynamic social life. To lead to the proper achievement of IPS learning objectives, then it is chosen the learning model. In this case, Kosasih (1978/1979) presented the IPS learning models, one of which is a problem-based learning model. 


\section{2013 Curriculum}

The 2013 curriculum learning uses a scientific or scientific-based approach. The scientific approach can apply some strategies, such as contextual learning. One of the learning strategies that can be applied in the learning based on the 2013 curriculum is the problem-based learning model.

TABLE I. SCIENTIFIC APPROACH

\begin{tabular}{|c|c|c|}
\hline $\begin{array}{c}\text { Learning } \\
\text { Stages }\end{array}$ & Activity Description & Forms of Learning Outcomes \\
\hline Observing & $\begin{array}{l}\text { Observe with the } \\
\text { senses (reading, } \\
\text { listening, listening, } \\
\text { seeing, watching, etc.) } \\
\text { with or without tools. }\end{array}$ & $\begin{array}{l}\text { Paying attention when } \\
\text { observing any object / } \\
\text { reading a writing /listening at } \\
\text { an explanation, notes made } \\
\text { about one observed, patience, } \\
\text { time (on task) used to } \\
\text { observe. }\end{array}$ \\
\hline Questioning & $\begin{array}{l}\text { Creating and giving } \\
\text { questions, Questions } \\
\text { and Answers, } \\
\text { discussing information } \\
\text { that is not understood, } \\
\text { inquiring additional } \\
\text { information to know or } \\
\text { as a clarification. }\end{array}$ & $\begin{array}{l}\text { Type, quality, and number of } \\
\text { questions proposed by } \\
\text { learners (factual, conceptual, } \\
\text { procedural, and hypothetic } \\
\text { questions) }\end{array}$ \\
\hline $\begin{array}{l}\text { Gathering } \\
\text { information/ } \\
\text { experimenting }\end{array}$ & $\begin{array}{l}\text { Exploring, trying, } \\
\text { discussing, } \\
\text { demonstrating, } \\
\text { imitating forms/moves, } \\
\text { conducting } \\
\text { experiments, reading } \\
\text { sources not only } \\
\text { textbooks, collecting } \\
\text { data from resources not } \\
\text { only persons but } \\
\text { through questionnaires, } \\
\text { interviewing, and } \\
\text { modifying/ } \\
\text { adding/developing. }\end{array}$ & $\begin{array}{l}\text { The number and quality of } \\
\text { the resources reviewed/used, } \\
\text { the completeness of } \\
\text { information, the validity of } \\
\text { the information collected, and } \\
\text { the instruments/tools used to } \\
\text { collect the data. }\end{array}$ \\
\hline $\begin{array}{l}\text { Reasoning/ } \\
\text { associating }\end{array}$ & $\begin{array}{l}\text { Processing the } \\
\text { collected information, } \\
\text { analyzing the data in } \\
\text { the form of creating } \\
\text { categories, associating } \\
\text { or linking related } \\
\text { phenomena/informatio } \\
\mathrm{n} \text { in order to find a } \\
\text { pattern, and to draw a } \\
\text { conclusion. }\end{array}$ & $\begin{array}{l}\text { Developing interpretations, } \\
\text { arguments and conclusions } \\
\text { about the information } \\
\text { interconnectedness of two } \\
\text { facts / concepts, } \\
\text { interpretations, arguments } \\
\text { and conclusions about the } \\
\text { interconnection of more than } \\
\text { two facts / concepts / } \\
\text { theories, synthesizing and } \\
\text { arguing and concluding the } \\
\text { interrelatedness of various } \\
\text { types of facts / concepts / } \\
\text { theories / opinions; } \\
\text { Developing interpretations, } \\
\text { new structures, arguments, } \\
\text { and conclusions showing } \\
\text { factual / conceptual } \\
\text { relationships of two or more } \\
\text { non-conflicting sources; } \\
\text { Developing interpretations, } \\
\text { new structures, arguments } \\
\text { and conclusions from } \\
\text { different concepts / theories / } \\
\text { opinions from different types } \\
\text { of sources. }\end{array}$ \\
\hline Communicating & $\begin{array}{l}\text { Presenting a report in } \\
\text { the form of charts, } \\
\text { diagrams, or graphs, } \\
\text { compile a written } \\
\text { report, and presenting a } \\
\text { report covering the } \\
\text { results and conclusions } \\
\text { orally }\end{array}$ & $\begin{array}{l}\text { Presenting results of the study } \\
\text { (from observing to reasoning) } \\
\text { in the form of writing, } \\
\text { graphics, electronic media, } \\
\text { multimedia, and others. }\end{array}$ \\
\hline
\end{tabular}

The 2013 Curriculum is implemented by using direct instructional and indirect instructional. The direct learning is the learning of developing knowledge, thinking ability, and skills using student knowledge through direct interaction with learning resources designed in syllabus and lesson plans. The direct learning direct produces knowledge and skills called the instructional effect. In the direct learning, the students perform $5 \mathrm{M}$ activities in the scientific approach, including: (1) observing activities, (2) questioning activities, (3) gathering information/experimenting, (4) reasoning/association activities, (5) communicating activities. The description of the learning stages of the scientific approach can be seen in the Table 1.

The indirect learning is the learning during the process of direct learning conditioned to produce the nurturant effect. The indirect learning is related to the values of attitudes presented in KI 1 and KI 2. This is different from the knowledge of values and attitudes applied in the direct learning process found in religious education and PPKN subjects. The development of values and attitudes as a process of value and behavior development is applied in all subjects and in every activity in the classroom, school, and community. Therefore, in the 2013curriculum-based learning process, all intra-curricular, co-curricular, and extracurricular activities both in class, school, and society are designed in order to develop moral and behavior related to values and attitudes.

\section{DISCUSSION}

The implementation of Student Facilitator And Explaining (SFAE) model for the IPS learning in elementary school based on the 2013 curriculum can be applied in IV, V, and VI classes. The Student Facilitator And Explaining (SFAE) model improves learning activeness as well as create students' learning motivation so that students can be more active and this practices their critical thinking skill. The implementation of IPS learning by using Student Facilitator And Explaining (SFAE) model is necessary to be welladjusted to the students' thinking skills and available supporting facilities

Examples of the implementation of Student Facilitator And Explaining (SFAE) learning model in IV class 2nd semester, with the Theme: The Beauty of Diversity in My Country. Sub Theme: the beauty of cultural diversity in my country. Meanwhile, the Basic Competence is: to identify the diversity of cultures, ethnics, and religions in the local province as Indonesian identity as well as its relationship with the space characteristics. Indicator: Presenting some traditional houses in Indonesia. The learning implementation is as follow: (a) Pre-Activity: the teacher gives an opening greeting, prayer, and presentation. (b) initial Activity includes: teacher conducts apperception concerning the traditional houses in Indonesia, then the teacher delivers the materials to be studied, as well as the learning purposes. (c) Core Activity includes: stages in the Student Facilitator And Explaining (SFAE) learning model with scientific learning.

First, observing. The teacher provides examples of East Java traditional house based on the learning purposes so that the students can observe it and then mention three unique characteristics of East Java traditional house after they observe. Second, questioning. The students giving questions 
and answers about the traditional house that has presented by the teacher, this aims to train students to be brave in delivering any questions and critical thinking. Third, gathering information/ experimenting. Teachers organize students to learn, namely, students are divided into groups to discuss or demonstrate, explore traditional houses, the teacher, in this case, guides the investigation of both individual and group.

Besides, the teacher also ensures all students to be involved in learning so that the students can be active in the learning process. Four, reasoning. Is the students in a group develop their finding concepts and present it in the form of report results of group tasks as the findings for their ideas or argumentation. Five, communicating. Each student is asked to explain to his friend about the material discussed in front of the class in turns, this aims to train students to have the bravery to express their opinions and at the same time train the students to become facilitators. The next step is that the teacher summarizes the ideas/opinions taken from the students and explains the materials being studied. (D) final activity: students and teachers conclude the learning materials create evaluation, reflection, and end with prayer.

\section{CONCLUSION}

Student Facilitator And Explaining (SFAE) is one of the learning models that can be applied to the 2013 curriculumbased IPS learning in elementary school. The Student
Facilitator And Explaining (SFAE) model is a learning model that can support the active, innovative and be enjoyable learning in the IPS learning in elementary school, because this learning model can improve students' activeness in the learning, train their bravery to explain to their friends on any things they are learning on. Also, the Student Facilitator And Explaining (SFAE) model is considered to be more enjoyable and preferred by the students because the students are involved directly and actively in the learning.

\section{REFERENCES}

[1] M. Huda, Model-model Pengajaran dan Pembelajaran Isu-isu Metodis dan Pragmatis. Yogyakarta: Pustaka Pelajar, 2013.

[2] A. Shoimin, Model Pembelajaran Inovatif dalam Kurikulum 2013. Yogyakarta: Ar-ruzz Media, 2014.

[3] Sapriya, Penddidikan IPS. Bandung: Remaja Rosdakarya, 2009.

[4] dkk Hidayati, "Pengembangan Pendidikan IPS SD." Directorate of General of High Education Departement of National Education, 2008.

[5] Depdikbud, "Permendikbud No 22." Depdikbud, 2006.

[6] Sumaatmaja, Konsep Dasar IPS. Jakarta: Universitas Terbuka, 2003.

[7] Trianto, Model-model Pembelajaran Inovatif. Ja: Grasindo, 2007.

[8] N. W. Rochmadi, "Naskah IPS SD. Education and Training of Profession of Teachers Rayon 15 State University of Malang." Committee of Teacher Certification of UMS, 2008.

[9] E. Mulyasa, Menjadi Guru Profesional. Bandung: PT Remaja Rosdakarya, 2006. 